\title{
OPINION
}

\section{On the generic classification of the rattlesnakes, with special reference to the Neotropical Crotalus durissus complex (Squamata: Viperidae)}

The generic-level classification of the rattlesnakes has been almost entirely stable throughout the $20^{\text {th }}$ and $21^{\text {st }}$ centuries: virtually all authors recognise two genera, Sistrurus Garman, 1884 for species with large, regular head shields, and Crotalus Linnaeus, 1758 for the species with fragmented head scales (Stejneger 1895, Boulenger 1896, Gloyd 1940, Klauber 1956, Campbell \& Lamar 2004). The only recent alteration has been the recognition that the taxon Crotalus ravus Cope, 1865, long placed in Sistrurus on account of its large head shields, shares a more recent common ancestor with species of Crotalus than with the other two Sistrurus, leading to its transfer to Crotalus (Murphy et al. 2002, Campbell \& Lamar 2004).

The rattlesnakes of South America and tropical Central America have consistently been placed in Crotalus, although the delimitation of species and subspecies within the Crotalus durissus complex has been a lengthy process that is still ongoing (Vanzolini \& CallefFo 2002, Campbell \& Lamar 2004, Wüster et al. 2005).

Recently, Hoser (2009a) published a reclassification of the rattlesnakes, which included the resurrection of three previously described genera (Aechmophrys Coues, 1875, Caudisona Laurenti, 1768, and Uropsophus Wagler, 1830) and the description of four new genera and seven new subgenera. Hoser provided no new data or analyses, but defined his taxa on the basis of the published phylogeny of MuRPHy et al. (2002). His actions have been ignored in most of the herpetological literature, and ZAHER et al. (2009) recommended against using Hoser's taxonomy.

Since 2004, the Brazilian Society of Herpetology maintains on the World Wide Web a constantly updated checklist of reptile species occurring in Brazil (BÉRNILS 2010). In order to accommodate the diversity of views among the herpetologists who cooperate in the maintenance of this checklist while maintaining the checklist as up to date as possible, it was necessary to assume a nonaligned attitude toward the adoption of taxonomic proposals as they are published monthly in the specialized literature. Consequently, every herpetological taxonomic change is immediately incorporated into the list without consideration of its merits, and is retained until its rejection in a subsequent paper. Therefore, from Hoser (2009a) to the present, the Brazilian List adopted the name Caudisona durissa for South American rattlesnakes, and this listing has resulted in the use of that name in non-taxonomic papers published by some Bra- zilian herpetologists (e.g. Araújo et al. 2010, LoEBMANN \& HADDAD 2010, Nogueira et al. 2010, Oliveira et al. 2010, Rocha \& Prudente 2010, SANTos 2010, SouzA et al. 2010; but see Costa et al. 2010), as well as a number of web pages, in spite of the lack of acceptance of Hoser's proposal outside Brazil.

This situation creates a problematic artefact with unexpected consequences because of a number of problems associated with Hoser's reclassification and the recognition of Caudisona Laurenti. These problems relate to the question of whether Crotalus should be subdivided at all, whether our understanding of the phylogeny of the rattlesnakes is sufficient to allow a reclassification if it were felt to be useful, and the status of Hoser's publication under the International Code of Zoological Nomenclature (ICZN).

All the available evidence from multiple analyses of the phylogeny of the Viperidae strongly supports the monophyly of the rattlesnakes as a whole (Gutberlet \& Harvey 2002, Castoe $\&$ PARKINSON 2006). Moreover, several analyses have confirmed the reciprocal monophyly of Crotalus (including C. ravus) and Sistrurus (Murphy et al. 2002, Castoe \& Parkinson 2006). There is thus no objective phylogenetic basis for dividing either of these genera: such an act would merely disturb the stability of the nomenclature (MurPHy et al. 2002).

Additionally, our understanding of the phylogeny of the rattlesnakes remains insufficient to justify taxonomic action at the present time. Although Hoser's classification is based on, and thus consistent with, one published phylogeny of the rattlesnakes (Murphy et al. 2002), it is inconsistent with a more recent phylogeny that included the same species (CASTOE \& PARKINSON 2006). Under the latter phylogeny, three of the genera and one of the subgenera recognised by Hoser would be non-monophyletic (see also ZaHer et al. 2009). Moreover, in both phylogenies, many basal nodes lacked support. Even if the division of Crotalus were deemed desirable, the lack of consensus between recently published studies shows that we still lack the evidential basis for a robustly supported, objective splitting of.

Finally, additional problems arise from the nature of Hoser's publication. The Australasian Journal of Herpetology is published by Hoser's own publishing company, Kotabi Pty Ltd., with eight published issues since January 2009. Hoser is the journal's sole editor and remains its only author. WALLACH et al. (2009) analysed the availability of this publication, with par-

\footnotetext{
${ }^{1}$ The articles in the section OPINION are of sole responsibility of the authors and do not necessarily reflect the views of the editorial board.
} 
ticular reference to Issue 7 (Hoser 2009b), dealing with elapids of Naja. The "published" issues of this periodical do not constitute published work according to the ICZN: Hoser's claims notwithstanding, Wallach et al. (2009) found no evidence for the existence of a printed edition consisting of multiple copies, as required by Article 8.1.3 of the ICZN. Only a single printed copy of Issue 7 was located, in the Australian National Library (ANL), whereas there were none for the preceding issues 1-6, including Hoser (2009a), which only seem to be available on the internet. Hard copies supplied later appear to have been printed on demand, and do not qualify as published work (Article 9.7 of the ICZN). Consequently, none of the scientific names coined by Hoser in Issues 1-7 of the Australasian Journal of Herpetology are published under the provisions of the ICZN, and all are thus unavailable. The named taxa include a number of Australasian elapids and skinks as well as cobras and rattlesnakes.

The unavailability of Hoser's names under the ICZN does not affect the status of the name Caudisona Laurenti, 1768, resurrected from synonymy by him. However, it does render its recognition problematic in the context of the phylogeny of the rattlesnakes: recognition of Caudisona would make Crotalus paraphyletic in any published phylogeny. A strictly phylogenetic classification recognising Caudisona would therefore require the division of Crotalus into multiple genera, including the resurrection of Uropsophus and Aechnophrys, and would leave one or several clades in need of scientific names. Moreover, the phylogenies of Murphy et al. (2002) and Castoe \& Parkinson (2006) would have different implications for the classification of the remaining rattlesnakes if Caudisona were to be recognised.

In summary, we therefore recommend the continued use of the generic name Crotalus for the Neotropical rattlesnake, Crotalus durissus, as well as all other rattlesnakes not currently included in Sistrurus, both as the best reflection of our current understanding of the phylogeny of these animals, and as the best means for ensuring the stability of the nomenclature.

This episode also serves to illustrate how rapidly unwarranted taxonomic changes published outside the peer-reviewed scientific literature can, under some circumstances, result in unnecessary nomenclatural instability and confusion, even when the lack of merit of the proposed classification is clear to other taxonomists. It also highlights the difficulties faced by the authors of checklists in their attempts to make their lists up-to-date, yet consensual. Uncritical listing of unwarranted taxonomic work in an attempt to maintain neutrality can result in nomenclatural confusion, as shown here. On the other hand, a checklist that seeks to represent only consensus views is likely to remain severely out of date, as consensus on many taxonomic issues is often slow to arise. The problem is exacerbated by the fact that such checklists are often misinterpreted by other authors as "official" or mandatory listings (PAuLy et al. 2009). While there can be no simple and comprehensive solution to this problem, we suggest that the best approach for such lists would be to annotate the entries of taxonomically controversial taxa, providing a brief summary of any problems, and taking care to avoid generating a misguided perception of taxonomic certainty.

\section{LITERATURE CITED}

Araújo, C.O.; D.T. Corrêa Filho \& R.J. Sawaya. 2010. Serpentes da Estação Ecológica de Santa Bárbara, SP: um remanescente de Cerrado do Sudeste do Brasil. Biota Neotropica 10 (2): $235-245$.

BÉRNILS, R.S. 2010. Brazilian reptiles - List of species. Sociedade Brasileira de Herpetologia. Available online at http:// www.sbherpetologia.org.br [Accessed: 15/IX/2010].

Boulenger, G.A. 1896. Catalogue of the Snakes in the British Museum (Natural History) III. London, British Museum (Natural History).

Campbell, J.A. \& W.W. Lamar. 2004. The Venomous Reptiles of the Western Hemisphere. Ithaca, Comstock.

Castoe, T.A. \& C.L. Parkinson. 2006. Bayesian mixed models and the phylogeny of pitvipers (Viperidae: Serpentes). Molecular Phylogenetics and Evolution 39: 91-110.

Costa, H.C.; D.L. Pantosa; J.L. Pontes \& R.N. Feio. 2010. Serpentes do Município de Viçosa, Mata Atlântica do Sudeste do Brasil. Biota Neotropica 10: 352-378.

GLOYD, H.K. 1940. The Rattlesnakes, Genera Sistrurus and Crotalus. A Study in Zoogeography and Evolution. Chicago, Chicago Academy of Sciences, 270p.

Gutberlet, R.L. \& M.B. Harvey. 2002. Phylogenetic relationships of New World pitvipers as inferred from anatomical evidence, p. 51-68. In: G.W. Schuett; M. Höggren; M.E. Douglas \& H.W. Greene (Eds). Biology of the Vipers. Eagle Mountain, Eagle Mountain Publishing.

Hoser, R. 2009a. A reclassification of the rattlesnakes; species formerly exclusively referred to the genera Crotalus and Sistrurus. Australasian Journal of Herpetology 6: 1-21.

Hoser, R. 2009b. A reclassification of the true cobras; species formerly referred to the genera Naja, Boulengerina and Paranaja. Australasian Journal of Herpetology 7: 1-15.

KLAUBER, L.M. 1956. Rattlesnakes: Their Habits, Life Histories, and Influence on Mankind. Berkeley, University of California Press, $2^{\text {nd }}$ ed., XXX+740p.

Loebmann, D. \& C.F.B. Haddad. 2010. Amphibians and reptiles from a highly diverse area of the Caatinga domain: composition and conservation implications. Biota Neotropica 10: 227-256.

Murphy, R.W.; J. Fu; A. Lathrop; J.V. Feltham \& V. Kovac. 2002. Phylogeny of the rattlesnakes (Crotalus and Sistrurus) inferred from sequences of five mitochondrial DNA genes, p. 69-92. In: G.W. Schuett; M. Höggren, M.E. Douglas \& H.W. Greene (Eds). Biology of the Vipers. Eagle Mountain, Eagle Mountain Publishing.

Nogueira, C.; G.R. Colli; G. Costa \& R.B. Machado. 2010. Diversidade de répteis Squamata e evolução do conhecimento faunístico no Cerrado, p. 333-375. In: I.R. DinIz; J. MarinHo- 
Filho; R.B. Machado \& R.B. Cavalcanti (Eds). Cerrado: conhecimento científico quantitativo como subsídio para ações de conservação. Brasília, Universidade de Brasília.

Oliveira, E.S.; D.F. Torres; S.E. Brooks \& R.R.N. Alves. 2010. The medicinal animal markets in the metropolitan region of $\mathrm{Na}-$ tal City, northeastern Brazil. Journal of Ethnopharmacology 130: 54-60.

Pauly, G.B.; D.M. Hillis \& D.C. Cannatella. 2009. Taxonomic freedom and the role of official lists of species names. Herpetologica 65 : 115-128.

Rocha, W.A. \& A.L.C. Prudente. 2010. The snake assemblage of Parque Nacional de Sete Quedas, State of Piauí, Brazil. South American Journal of Herpetology 5 (2): 132-142.

SANTos, V. 2010. A interface saúde/cultura/ciência: a tessitura de discursos sobre o uso de plantas, animais e simpatias como terapia curativa. Revista Metáfora Educacional 8: 71-86.

Souza, F.L.; M. Uetanabaro; P. Landgref-Filho; L. Piatti \& C.P.A. Prado. 2010. Herpetofauna, municipality of Porto Murtinho, Chaco region, state of Mato Grosso do Sul, Brazil. Check List 6 (3): 470-475.
Stejneger, L. 1895. The Poisonous Snakes of North America. Washington, DC, Government Printing Office.

VAnZolin, P.E. \& M.E.V. CAllefFo. 2002. A taxonomic bibliography of the South American snakes of the Crotalus durissus complex (Serpentes, Viperidae). Anais da Academia Brasileira de Ciências 74: 37-83.

Wallach, V.; W. WÜster \& D.G. Broadley. 2009. In praise of subgenera: taxonomic status of cobras of the genus Naja (Serpentes: Elapidae). Zootaxa 2236: 26-36.

Wüster, W.; J.E. Ferguson; J.A. Quijada-Mascareñas; C.E. Pook; M.G. Salomão \& R.S. Thorpe. 2005. Tracing an invasion: landbridges, refugia, and the phylogeography of the Neotropical rattlesnake (Serpentes: Viperidae: Crotalus durissus). Molecular Ecology 14: 1095-1108.

Zaher, H.; F.G. Grazziotin; J.E. Cadle; R.W. Murphy; J.C. MouraLeite \& S.L. BonatTo. 2009. Molecular phylogeny of the advanced snakes (Serpentes, Caenophidia) with an emphasis on South American Xenodontines: a revised classification and descriptions of new taxa. Papéis Avulsos de Zoologia 49: 115-153.

\section{Wolfgang Wüster ${ }^{1} \&$ Renato S. Bérnils ${ }^{2,3}$}

1 School of Biological Sciences, Bangor University, Bangor LL57 2UW, UK. E-mail: w.wuster@bangor.ac.uk

${ }^{2}$ Departamento de Ciências Agrárias e Biológicas, Centro Universitário Norte do Espírito Santo, Universidade Federal do Espirito Santo. 29932-540 São Mateus, ES, Brazil. E-mail: renatobernils@terra.com.br

${ }^{3}$ Corresponding author.

Submitted: 03.XI.2010; Accepted: 13.VII.2011.

Editorial responsibility: Ana Lúcia da C. Prudente 